\title{
Occurrence and Seasonal Variation of Escherichia coli Isolated from Unpasteurised Raw Milk and its Products Sold in Abuja Metropolis, Nigeria
}

\author{
E.C. Okechukwu ${ }^{1}$, E.U. Amuta ${ }^{2}$, G.M. Gberikon ${ }^{1}$ and M. Njoku ${ }^{3}$ \\ ${ }^{1}$ Department of Microbiology, ${ }^{2}$ Department of Zoology, \\ Federal University of Agriculture, Makurdi, Nigeria \\ ${ }^{3}$ Department of Microbiology and Biotechnology, \\ National Institute for Pharmaceutical Research and Development, Abuja, Nigeria \\ *Corresponding author
}

A B S T R A C T

\section{Keywords}

Escherichia coli, Unpasteurised raw milk, Milk products, Hygiene, Sanitary conditions

Article Info

Accepted:

17 April 2019

Available Online:

10 May 2019
Raw milk and milk products are traditional staple diets that are popularly consumed by both rural and urban population of Northern Nigeria and many other parts of Africa. The aim of the study was to isolate $E$. coli from unpasteurised raw milk and milk products (Madara, Kindrimo, Nono and Manshanu) during the rainy and dry seasons in Abuja in order to ascertain the hygienic status of the dairy products. Three hundred unpasteurised raw milk and its products were collected in both rainy and dry seasons respectively. Escherichia coli was isolated by microbiological techniques and confirmed by Microbact $^{\mathrm{TM}}$ (Oxiod $^{\mathrm{TM}}$ ) GNB 24E System Identification Kit. Results showed that dry season had higher occurrence of $E$. coli $(21,7.0 \%)$ while occurrence during rainy season was $(14,4.7 \%)$. There was no statistically significant difference in occurrence of $E$. coli isolates during the two seasons $(p>0.05)$. These ready to eat dairy products frequently harbor coliforms that indicates poor hygiene and insanitary conditions possibly during processing and cause infections that are of great public health importance. Educating the milk handlers on the importance of personal hygiene and proper sanitary methods is necessary.

\section{Introduction}

Consumption of fresh produce is part of a healthy diet, but pathogen contamination of fresh produce has resulted in serious public health consequences (Jung et al., 2014). Globally, the number of outbreaks and cases of foodborne illness associated with consumption of contaminated food continues to escalate (Teplitski et al., 2011; Hoelzer et al., 2012). Marketers and consumers of unpasteurised raw milk and their products have existed in many parts of the world. Unpasteurised raw milk is consumed directly by a large number of people in rural areas and indirectly by a much larger segment of the population by consuming the raw milk and its products. Reasons that people may believe 
that the raw milk and their products have beneficial dietary effects and additional nutritive value over the pasteurised one (Ali and Abdelgadir, 2011).

Raw milk and milk products of dairy cattle are known repository of food borne pathogens (Enabulele et al., 2014). The presence of food borne pathogens in milk has been traced to direct contact with contaminated sources in the dairy farm environment particularly from water source, and excretion from the udder of an infected animal (Oliver et al., 2005). Contamination of milk and milk products, with pathogenic bacteria is largely due to processing, handling, and utensils used for the storage of milk on farm or during transportation and unhygienic conditions. Nono, Kindrimo, Manshanu and Madara are local dairy products that are widely consumed as food especially in the northern part of Nigeria, and these have been reported to contain high nutritional values (Makut et al., 2014). Escherichia coli which belongs to the Enterobacteriaceae family, is a Gramnegative, facultative anaerobic, nonsporulating bacteria. It is widely distributed in intestinal microbiota of humans and warmblooded animals and in the environment, when contaminated with feaces (Nataro and Kaper, 1998; Smith et al., 2004).

Escherichia coli and other coliforms are microbes that can easily contaminate milk and milk products, which are often used as indicator organisms. The recovery and remuneration of $E$. coli is used as reliable indicator of feacal contamination and indicates a possible presence of enteropathogenic and/or toxigenic microorganisms which constitute a public health hazard.

Most E. coli are harmless, but a substantial population is known to be pathogenic bacteria, causing severe intestinal and extra intestinal diseases in man (Kaper et al., 2004). Owning to the fact that these ready-to-eat dairy products are processed by 'too simple' a method and the knowledge on the microbial limit especially the coliforms is barely unknown. There are scanty reports on the microbiological quality of milk and its product in Nigeria. The aim of the study was to determine the presence of Enterobacteriaceae, Escherichia coli a coliform as an indicator of unsanitary practices in food during the two major seasons of the year.

\section{Materials and Methods}

\section{Sample location}

The study was carried out in Abuja, the Federal Capital Territory (FCT) located in the geographical Centre of Nigeria with a land area of 8, 000 square kilometres and lies between latitude $9^{\circ} 10^{\prime}$ north of the equator and longitude $7^{\circ} 11^{\prime}$ east. It is bounded North by Kaduna state (North), Niger state (West), Nasarawa state (East) and Kogi state (South) (Dawam, 2000). It is made up of six Area Councils namely, Abaji, AMAC (Abuja Municipal Area Council), Bwari, Gwagwalada, Kuje and Kwali. The study area experiences two weather conditions annually which are the rainy season and the dry season. The rainy season begins from April and ends in October and the dry season from November and ends in March (Abdulmalik et al., 2013).

\section{Sample collection}

Three hundred (300) milk samples were randomly collected from the six Area Councils at various points in dry and rainy seasons respectively. Samples were aseptically collected in duplicates at point of sales in sterile plastic containers, labeled and transported in ice box to the laboratory for immediate analysis. 
Microbiological analysis/ sample enrichment, selective and differential plating

Ten millilitres $(10 \mathrm{ml})$ of the unpasteurised raw milk samples were transferred into $90 \mathrm{ml}$ of modified Tryptic Soy broth (mTSBn) (oxoid) supplemented with $20 \mathrm{mg} / \mathrm{l}$ novobiocin (oxoid) homogenized for 2minutes in a stomacher (Lab Blender 400, Seward Medical, London, UK) and then incubated at $37^{\circ} \mathrm{C}$ for 18 hours as E. coli enrichment step. A loopful of the enriched broth was streaked on the plate of Eosin Methylene blue agar (EMB), (oxoid) and after overnight incubation at $37^{\circ} \mathrm{C}$. Suspected colonies of $E$. coli (greenish metallic sheen appearance with dark purple centres) were Gram stained, biochemically identified and confirmed.

\section{Biochemical characterization of Escherichia coli}

The presumptive Gram stained E. coli were subjected to conventional biochemical tests namely, Gelatin liquefaction, Nitrate reduction, Urease production, Oxidase, Indole-methylred-Voges-Proskauer, Catalase, Citrate Agar, and Sugar fermentation tests (Müller et al., 2003).

Confirmatory screening of presumptive $E$. coli MICROBACT ${ }^{\mathrm{TM}}$ GNB 24E system identification

Confirmatory screening was carried out on the presumptive Gram stained E. coli isolates using MICROBACT TM24E. The isolates were subsequently confirmed using the commercially prepared biochemical test kits (Microbact Oxoid). The MICROBACT ${ }^{\mathrm{TM}}$ identification kits (Oxiod) were inoculated with the E. coli suspension, incubated at $37^{\circ} \mathrm{C}$ for 18-24hours and results read as described by the manufacturer. The steps of the procedure were followed as prescribed by Cowen and Steel (1977), Balows et al. (1991).

\section{Statistical Analysis}

The data generated in this study was analyzed by Chi Square test using SPSS version 20.0. The value of $(\mathrm{p}<0.05)$ was considered statistically significant.

\section{Results and Discussion}

The percentage occurrence of E. coli during the dry season (Table 1$)$, was $(21,7.0 \%)$. The highest percentage occurrence among the four milk types was Madara $(10,14.3 \%)$, followed by Kindrimo (6, 6.7\%), Nono (3, 3.8\%) and Manshanu $(2,3.3 \%)$. Though the percentage occurrence of $E$. coli in the milk samples differed during the dry season, there was no statistically significant difference $\left(\chi^{2}=7.381\right.$, $\mathrm{df}=3, \mathrm{P}=0.061)$ in the occurrence of $E$. coli during the dry season. This indicates that dry season did not affect the growth of Escherichia coli at the period of this study.

Table 2 shows the percentage occurrence of E. coli during the rainy season $(14,4.67 \%)$. Madara had the highest percentage of occurrence $(5,6.02 \%)$, followed by Kindrimo $(4,5.7 \%)$, Nono $(3,3.9 \%)$ and Manshanu (2, $2.9 \%)$. Though, there seemed to be varying percentages of occurrence of $E$ coli in the different milk samples, there was no statistically significant difference $\left(\chi^{2}=1.429\right.$, $\mathrm{df}=3, \mathrm{P}=0.699)$ in the occurrence of $E$. coli during the rainy season, which indicates that rainy season did not affect the survival and growth of Escherichia coli in the milk products at the time of this study.

Figure 1 displays the overall distribution of $E$. coli in the two seasons (dry and rainy season), from the four milk products. Madara had the highest occurrence in the dry season $(10$, 
$14.3 \%)$ and highest in the rainy season (5, $6.0 \%)$ and total of $(15,9.8 \%)$ followed by Kindrimo $(6,6.7 \%)$ in the dry season and (4, $5.7 \%)$ in the rainy season with total of $(10$, $6.3 \%)$, Nono had $(3,3.8 \%)$ in the dry season and $(3,3.9 \%)$ in the rainy season with total of $(6,3.8 \%)$ while Manshanu had the lowest occurrence of E. coli $(2,2.9 \%)$ in the dry season and $(2,3.3 \%)$ in the rainy season with total of $(4,3.1 \%)$.

Unpasteurised raw milk and milk products are nutrient rich sources of food (Momtaz et al., 2012; Egwaikhide et al., 2014; Igwegbe et al., 2015) and has become a significant part of human diet (Igwegbe et al., 2015). The complex composition and water activity of raw milk (Soomro et al., 2002), which makes it a favourable medium that supports the growth and survival of various microorganisms (Mohamed and El-Zubeir, 2007) either pathogenic or non-pathogenic strains which may result in desirable and undesirable products in the milk (Yagoub et al., 2005; Ogbonna et al., 2012) or may cause infections and intoxications in humans when consumed (Oliver et al., 2005).

Several researchers have reported on the poor microbiological quality of unpasteurised raw milk, tracing the contamination of these milk and milk products to some factors such as unhygienic practices of the milkers/handlers (Soomro et al., 2002; Abebe et al., 2014), insanitary vessels/utensils for storage and temperature (Leedom, 2006; Campos et al., 2009; Momtaz et al., 2012), environment and infected milk producing animals(Momtaz et al., 2012; Caine et al., 2013; Jeyakumar and Lawrence, 2014), and contaminated water (Abdalla and El-Zubeir, 2006; Momba et al., 2008). Escherichia coli is one of the most frequently encountered microorganisms in the food industry (Adeferekan et al., 2014). Various disease outbreaks have been reported to be due to ingestion of food contaminated with pathogenic E. coli strains (Pradel et al.,
2000). Previous studies suggested that raw milk and various dairy products samples were considered to be the primary source of $E$. coli (Gundogan and Avci, 2014; Abebe et al., 2014).The production of these milk products is based on traditional methods (bare hands) without any regard to the quality of raw materials used and the safe quality of the products (Soomro et al., 2002; Campos et al., 2009).

In developing countries, it is difficult to secure optimal food hygienic practices (Abebe et al., 2014), and under such prevailing conditions microorganisms gain entry into the milk and its products. One of such microorganisms is Escherichia coli. Escherichia coli is an environmental pathogen (Caine et al., 2013), a frequently contaminating organism, and is a reliable indicator of feacal contamination generally in insanitary conditions and poor hygiene of water, food, milk and other dairy products (Diliello,1982; Thaker et al., 2012). The status of Escherichia coli as pathogen and its presence in food constitutes public health concern (Caine et al., 2013). The recovery of E. coli from unpasteurised raw milk and milk products samples in this study agrees with reports of other researchers (Adesiyun et al., 1997; Onono et al., 2010; Ali and Abdelgadir, 2011; Rahimi, 2011; Cain et al., 2013; Enabulele et al., 2014; Gundogan and Avci, 2014; Makut et al., 2014).

It also suggested that the methods of production, handling during processing, transportation and sales of these ready-to-eat food are entirely insanitary thereby exposing the milk samples to microbial contamination (Ali and Abeldagir, 2011). The nosedive in the aspect of sanitary practices could cause food borne diseases (Ijah et al., 2002), especially among urban residents who drink fresh milk sold by the Fulani women (Okeke et al., 2014). The presence of bacterial contamination of raw milk and milk products 
especially by coliform, Enterobacteriaceae particularly E. coli have been evaluated and reported by several researchers (Soomro et al., 2002; El-Zubeir and Ahmed 2007; Ali and Abdelgadir 2011; Momtaz et al., 2012; Ogbonna et al., 2012; Caine et al., 2013; Abebe et al., 2014; Vendramin et al., 2014; Al-Zogibi et al., 2015; Enem et al., 2015; Mohammed and Abdullahi, 2015; Saba and Adzitey, 2015).

The presence of E. coli indicates that the control of raw material manufacturing processes and the final product is inefficient (Campos et al., 2009). Escherichia coli is a frequently occurring microorganism in milk and milk products. This implies that the microbial contamination of these milk and its products is not far-fetched from the predisposing factors such as the insanitary conditions, unhygienic state of the milkers, insects and dusts (Momtaz et al., 2012; Abebe et al., 2014).

Several findings from different researchers showed high prevalence of $E$. coli in raw milk; Saba and Adzitey (2015) (49.3\%) in Ghana; Abebe et al., (2014) (26.6\%) in Ethiopia; Ali and Abdelgadir (2011), (63\%) in Sudan; in Turkey, Gundogan and Avci, (2014) (74\%); in Brazil, Vendramin et al., (2014) (53.5\%); (Campos et al., (2009) (79.2\%); Meshref (2013) (52.6\%) in Egypt; Thaker et al., (2012) (30\%) in India; Mailafia et al., (2017) (27.3\%) in Abuja, Nigeria; Caine et al., 2014 (45\%) in South Africa; Shah et al., (2016) (33.3\%) in Malaysia.

This is an indication that the presence of $E$. coli in raw milk provides evidence that unpasteurised raw milk could be a vehicle of transmission of food borne pathogens possibly carrying enterohaemorrhagic/ enteropathogenic and/or toxigenic microorganisms which could constitute a public health hazard (Ali and Abdelgadir, 2011).

Abebe et al. (2014) reported that raw milk is a vehicle and medium of growth for E. coli. The presence of $E$. coli implies a risk that other enteric pathogens may be present in the food samples (Meshref, 2013). According to Meshref (2013), raw milk is the basic material from which all dairy products are made. The diversity of microorganisms and the level of contamination in the raw material have a decisive effect on the quality and safety of the final product.

Several factors could be responsible for the contamination of raw milk with $E$. coli namely the use of contaminated utensils, use of contaminated water, milk contact surfaces, contamination of milk with feaces, improper storage conditions, unhygienic milking equipments, milking enviroment (El-Zubeir and Ahmed, 2007), dirty hands (Bagréet al., 2014), infected animals (El-Zubeir et al., 2006) and storage and transport equipment (Altalhi and Hassan, 2009; Bityqi et al., 2011). Therefore, the implication of the presence of food borne pathogen in unpasteurised raw milk is that there is a high risk of ingestion of potentially harmful toxins and transmission of food-borne pathogens (Ali and Abdelgadir, 2011).

The result of this study showed higher occurrence of the E. coli in the dry season than during the rainy season. This finding corroborates with the reports of El- zubeir and Ahmed (2007) that higher bacterial counts are expected under tropical condition due to the fact that high temperatures enhances growth and multiplication of bacteria. Soomro et al., (2002) in Pakistan reported that raw milk is easily contaminated due to high ambient summer temperatures. 
Table.1 Frequency of occurrence of E. coli isolates from unpasteurised raw milk samples during dry season

\begin{tabular}{|l|l|l|l|}
\hline Sample Type & No. Screened & No. Positive & \% Positive \\
\hline Madara & 70 & 10 & 14.3 \\
\hline Kindrimo & 90 & 6 & 6.7 \\
\hline Nono & 80 & 3 & 3.8 \\
\hline Manshanu & 60 & 2 & 3.3 \\
\hline Total & 300 & 21 & 7.0 \\
\hline
\end{tabular}

$\left(\chi^{2}=7.381, \mathrm{df}=3, \mathrm{P}=0.061\right)$

Table.2 Frequency of occurrence of $E$. coli isolates from unpasteurised raw milk samples during rainy season

\begin{tabular}{|l|l|l|l|}
\hline Sample Type & No. Screened & No. Positive & \% Positive \\
\hline Madara & 83 & 5 & 6.0 \\
\hline Kindrimo & 70 & 4 & 5.7 \\
\hline Nono & 77 & 3 & 3.9 \\
\hline Manshanu & 70 & 2 & 2.9 \\
\hline Total & 300 & 14 & 4.7 \\
\hline
\end{tabular}

$\left(\chi^{2}=1.429 \mathrm{df}=3, \mathrm{P}=0.699\right)$

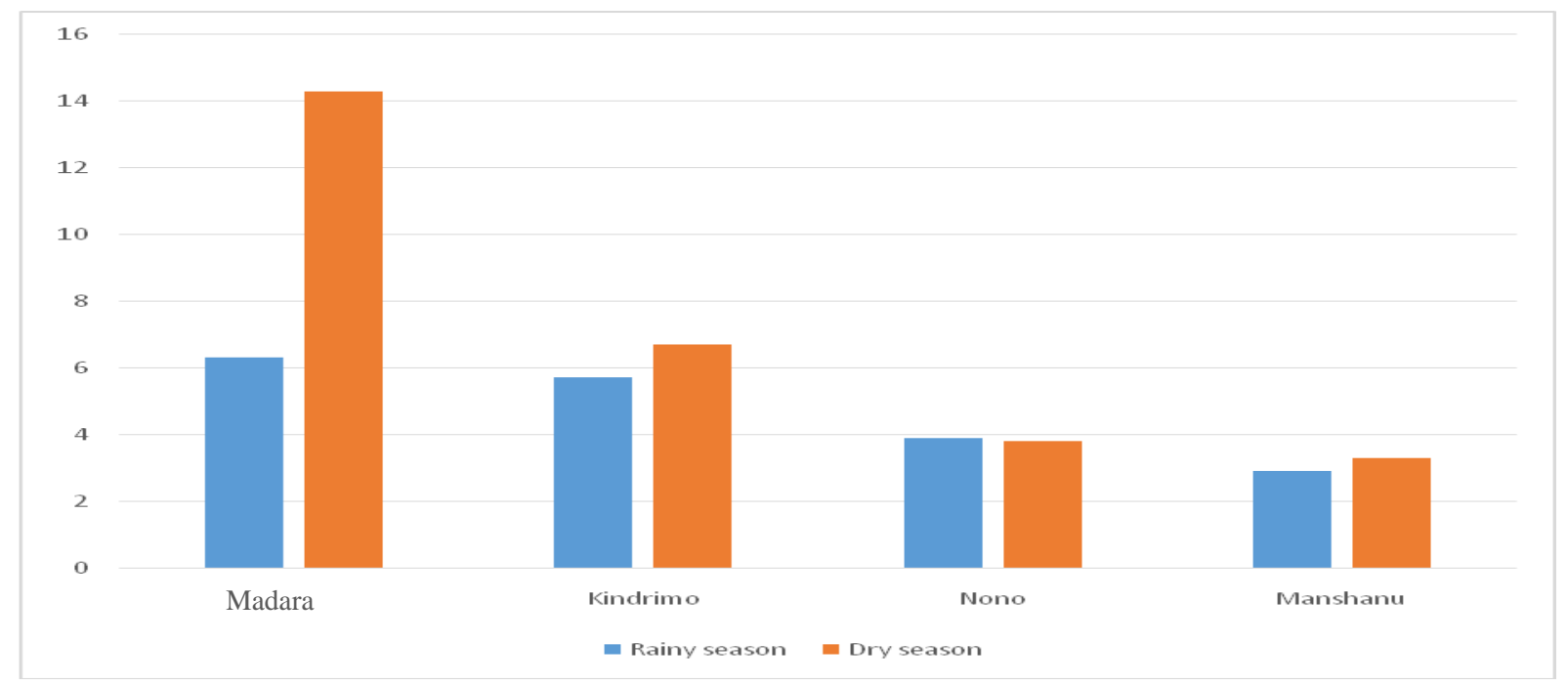

Fig.1 Relative percentage distribution of $E$. coli in rainy and dry seasons in unpasteurised raw milk samples 
In conclusion, the study has shown that unpasteurised raw milk and its products are not without microbial contamination. As a developing country, perhaps in this part of the globe there are no established acceptable microbial limits in dairy products. With the growing concerns over the hygienic status of ready-to-eat food, the government should be proactive in monitoring food of bovine origin especially the dairy products that are consumed without necessarily cooking and ensuring effective food surveillance programs in order to monitor locally made food especially produced from animal origin that are readily available to the populace.

\section{Recommendation}

Preventive measures such as regular hand washing and sterilization of dairy equipment, utensils, milker's hands, animal udders, and eradication of diseased animals from the herd are highly recommended. The reduction of faecal contamination in milk production to its barest minimal load is the key to control this pathogen in dairy farms.

\section{References}

Abdalla, M.E.M. and. El-Zubeir, I.E.M. (2007). Effects of different management practices on milk hygiene of goat farms in Khartoum State, Sudan. International Journal of Dairy Sciences, 2: 23-32.

Abdulmalik, R.O, Oyinbo, O., and Sami, R. A. (2013). Determinants of Crop Farmers Participation in Agricultural Insurance in the Federal Capital Territory, Abuja, Nigeria. Greener Journal of Agricultural Sciences 3 (1): 021-026

Abebe M. Hailelule, A. Abrha, B., Nigus A., Birhanu M., Adane H., Genene T. Daniel H. Getachew, G. Merga and Haftay A. (2014) Antibiogram of Escherichia coli strains selected from food of bovine origin selected in Woredas of Tigray, Ethiopia. Journal of Bacteriology
Research, 6(3): 17-22

Adefarakan, T. A., Oluduro, A. O., David, O. M., Ajayi, A. O., Ariyo, A. B., and Fashina, C. D. (2014). Prevalence of antibiotic resistance and molecular characterization of Escherichia coli from faeces of apparently healthy rams and goats in Ile-Ife, Southwest, Nigeria. Ife Journal of Science 16 (3)

Adesiyun, A.A., Webb, L.A. Romain, H. and Kaminjolo, J.S. (1997). Prevalence and Characteristics of Strains of Escherichia coli Isolated from Milk and Feces of Cows on Dairy Farms in Trinidad. Journal of Food Protection 60 (10) 174118.

Ali, A. A. and Abdelgadir, W.S. (2011). Incidence of Escherichia coli in Raw Cow's Milk in Khartoum State. British Journal of Dairy Sciences 2(1): 23-26, 2011.

Altalhi A.D., Hassan S.A. (2009). Bacterial quality of raw milk investigated by $E$. coli and isolates analysis for specific virulence -gene markers. Food Control; 20: 913917.

Al-Zogiby, G. O., Mohammed, M.I., Hessain, M.A., El-Jakee, J.K. Kabli, S.A (2015) Moleccular and serotyping characterization of shiga toxigenic Escherichia coli associated with collected from Saudi Arabia. Saudi Journal of Biological Sciences (22) 438-442

Bagré, T.S., Kagambèga, A., Bawa, H.I., Tchamba, G.B., Dembélé, R.E., Zongo, C., Savadogo, A., Aggad, H., Traoré, A.S. and Barro, N. (2014). Antibiotic susceptibility of Escherichia coli and Salmonella strains isolated from raw and curds milk consumed in Ouagadougou and Ziniar, Burkina Faso. African Journal of Microbiology Research 8(10), 10121016.

Balows, A., Hausier W.J., Hermann K.L., Isengeng, J.D. and Shadomy, J. H. (eds) (1991) Manual of Clinical Microbiology, $5^{\text {th }}$ Edition, American Society of Microbiology, Washington D.C.

Bytyqi, H., Bigler, S., Muji, S., Jahja, A., 
Zaugg, U. (2011) Survey on raw milk quality in Kosovo. Food and Nutrition Science 2011; 2: 414-421

Caine, L., Pekana, A., Lukanji, Z., Idamokoro, M., and Green, E. (2013) Pathogenic Escherichia coli strains in raw milk obtained from two farms of the Eastern Cape Province, South Africa. Mendel Net

Campos, M.R.H., André, M.C.D.P.B., Borges L.J., Kipnis A., Pimenta, F.C., Serafini, A.B. (2009) Genetic heterogeneity of Escherichia coli strains isolated from raw milk, Minas Frescal cheese, and food Arq. Bras. Med. Vet. Zootec., 61(5): 1203-1209,

Cowen, S. T. and Steel K.J. (1977) Manual for the identification of Medical Bacteria, $2^{\text {nd }}$ Edition Cambridge University.

Dawam, P.D. (2000) Geography of Abuja Federal Capital Territory. Famous and Ansala Publishers, Minna.

Diliello, L.R., (1982) Methods in Food and Dairy Microbiology. AVI Publishing Co. Inc. Westport Connt. USA: pp39

Egwaikhide, P. A., Malu, P. S., Lawal, U., Adelagun, R. O and Andrew, C. (2014). Physico-Chemical and Microbiological Analysis of Fermented Cow Milk (Nono) Consumed Within Kaduna Town, NorthWestern Nigeria. Food Science and Quality Management 29

El Zubeir, I. E. M. and Ahmed, M. I. A. (2007) The Hygienic Quality of Raw Milk Produced by Some Dairy Farms in Khartoum State, Sudan. Research Journal of Microbiology, 2: 988-991.

El-Zubeir, I.E.M., Kutzer, P. and. El-Owni, O.A.O. (2006). Frequencies and antibiotic susceptibility patterns of bacteria causing mastitis among cows and their environment in Khartoum state. Research Journal of Microbiology 1: 101-109.

Enabulele, S.A., Eghafona, N.O. And Dahiru, M. (2014) Molecular Characterisation And Verotoxigenic Potentials Of Enterohaemorrhagic Escherichia coli 0157:H7 isolated from fermented fresh cow milk (Nunu) sold in selected cities in Nigeria. Journal of Basic and Applied
Sciences 1(1): 51 - 62, 2014.

Enem, S.I., Oboegbulem, S.I., Nafarnda, W.D, Omeiza G.K. (2015). Detection of Verocytotoxigenic Escherichia coli $\mathrm{O} 157$ serotype in dairy products in Abuja, Nigeria. Open Journal of Veterinary Medicine 5, 224-228

Gundogan, N. and Avci, E. (2014) Occurrence and antibiotic resistance of Escherichia coli, Staphylococcus aureus and Bacillus cereus in raw milk and dairy products in Turkey. International Journal of Dairy Technology, 67(4).

Hoelzer, K., Pouillot, R., Egan, K., and Dennis, S. (2012) Produce consumption in the United States -An analysis of consumption frequencies, serving sizes, processing forms, and high-consuming population subgroups for microbial risk assessments. Journal of Food Protection 75: 328-340.

Igwegbe, A.O., Maina, F.J., Kassum, A.L., Agbara, G.I., Chibuzo, E.C., Badau, M. H. (2015) Evaluation and acceptability of yoghurt drink processed from goat milk and a combination of goat and cow milks. International Journal of Biotechnology and Food Science 3(4), pp. 41-48,

Ijah J.J., Odagboyi G, Uwabujo A.E. (2002) Microbiological screening of furan da nono. Nigeria Journal of Science Technology and Mathematical Education 5(1): 9-16

Jeyakumar E, and Lawrence, R. (2014). Prevalence of multi-drug resistant (MDR) Enteric bacteria in milk and milk products. Indian Journal of Dairy Science, 67.

Jung, Y., Jang, H. and Matthews, K. R. (2014) Effect of the food production chain from farm practices to vegetable processing on outbreak incidence. Microbial Biotechnology, 7(6), 517-527.

Kaper, J.B., J.P. Nataro and H.L.T. Mobley, (2004). Pathogenic Escherichia coli. Nat. Rev. Microbiology, 2: 123-140.

Leedom, J.M. (2006) Milk of non-human origin and infectious diseases in human. Clinical Infectious Diseases. 43, 610-615 
Mailafia, S., Olabode, H. O., Okoh, G., Jacobs, C., Adamu, G. S., Onyilokwu, A. S. (2017) Microbact ${ }^{\mathrm{TM}}$ 24E system identification and antimicrobial sensitivity pattern of bacterial flora from raw milk of apparently healthy lactating cows in Gwagwalada, Nigeria. Journal of coastal Life Medcine, 3(8): 356-359

Makut, M. D., Nyam, M. A., Amapu, T. Y., and Abbul-Mutalib Ahmed, AM. (2014) Antibiogram of bacteria isolated from locally processed cow milk products sold in Keffi metropolis, Nasarawa State, Nigeria. Journal of Biology, Agriculture and Healthcare, 4(4).

Meshref A M S (2013) Bacteriological quality and safety of raw cow's milk and fresh cream. Slovenian Veterinary Research 50 21-30.

Mohamed, N.N.I. and. El Zubeir, I.E.M. (2007). Evaluation of the hygienic quality of market milk of Khartoum State (Sudan). International Journal Dairy Sciences., 2: 33-41.

Mohammed A.S. and Abdullahi, M. (2015) Comparative study of microbial quality of hawked nono and packaged yogurt sold in Bida Metropolis. Specialty Journal of Psychology and Management Vol, 1 (0): $1-4$

Momba, M.N.B., Abong'o, B.O. and Mwambakana J.N. (2008) Prevalence of enterohaemorrhagic Escherichia coli O157:H7 in drinking water and its predicted impact on diarrhoeic HIV/AIDS patients in the Amathole District, Eastern Cape Province, South Africa. Water South Africa Vol. 34 (3)

Momtaz, H., Farzan R., Rahimi, E., Dehkordi F.S., and Souod, N. (2012) Molecular Characterization of Shiga ToxinProducing Escherichia coli Isolated from Ruminant and Donkey Raw Milk Samples and Traditional Dairy Products in Iran.

Momtaz, H., Dehkordi, F.S., Taktaz, T., Rezvani, A., Yarali, S. (2012) Shiga Toxin-Producing Escherichia coli: Isolated from Bovine Mastitic Milk:
Serogroups, Virulence Factors, and Antibiotic Resistance Properties. The Scientific World Journal 2012.

Müller, E.E., Grabow, W.O.K and MM Ehlers M.M. (2003) Immunomagnetic separation of Escherichia coli $0157: \mathrm{H} 7$ from environmental and wastewater in South Africa. Water South Africa (29): 4

Nataro, J.P., Kaper, J.B. (1998) Diarrheagenic Escherichia coli. Clinical Microbiological Review 1998; 11 (1): 142-201

Ogbonna, 1.O., David, A.B., Waba, J.T., Eze, P.C. (2012) Microbiological quality assessment of biradin, kesham and kindirmo (milk product) sold in Maiduguri Nigeria. International Journal of Dairy Science (1): 11-19.

Okeke K. S., Abdullahi, I. O. and Makun, H. A. (2014) Microbiology quality of dairy cattle products British Microbiology Research Journal 4(12): 1409-1417.

Oliver, S.P. Jayarao B.M. and Almedia, R.A. (2005). Food borne pathogens in milk and the dairy environment food safety and public health implications. Foodborne Pathogens and Disease, 2: 1115-1129

Onono, J. O., Erastus Kiambi Kangethe, E.K., and Ogara, W.O. (2010) Antimicrobial susceptibility of non-sorbitol fermenting Escherichia coli isolated from cattle feaces and milk samples. African Journal of Microbiology Research 4(16), Pp. 1703-1707,

Pradel, N., Livrelli, V., De Champs, C., Palcoux, J. B., Reynaud, A., Scheutz, F., Sirot, J., Joly, B., Forestier, C. (2000). Prevalence and characterization of Shiga toxin producing Escherichia coli isolated from cattle, food, and children during a one-year prospective study in France. Journal of Clinical Microbiology 38:1023-1031.

Rahimi, E., Chaleshtori, S.S. and Parsaei, P. (2011) Prevalence and antimicrobial resistance of Escherichia coli $\mathrm{O} 157$ isolated from traditional cheese, ice cream and yoghurt in Iran. African Journal of Microbiology Research 5(22), 3706-3710, 
Saba C.K.S., Yankey Eric and Frederick Adzitey (2015) Prevalence of Escherichia coli and shiga toxin producing Escherichia coli in cattle faeces and raw cow milk sold in the Tamale Metropolis, Ghana. Journal Of Dairy Veterinary And Animal Research 2 (5)

Shah, M. K. Aziz, S. A and Zakaria, Z. (2006) Occurrence of Escherichia coli and Escherichia coli $\mathrm{O} 157: \mathrm{H} 7$ in cattle, farm environment, milk and beef. Malaysian Journal of Microbiology (12) 3 Pp191198

Smith H., Willshaw G., Cheasty T.E. (2004) E coli as a cause of outbreaks of diarrhoeal disease in the UK. Microbiology Today 31 p 117-118

Soomro, A.H., Arain, M.A., Khaskheli, M. and Bhutto, B., (2002). Isolation of Escherichia coli from Raw Milk and Milk Products in Relation to Public Health Sold under Market Conditions at Tandojam. Pakistan Journal of Nutrition 1(3): 151-152

Sudda M. M., Mtenga, A. B., Kusiluka, L.J., NeemaKassim, N. (2016) Prevalence and antibiotic susceptibility of Escherichia coli and Salmonella Spp. Isolated From Milk Of Zero Grazed Cows In Arusha City. African Journal of Microbial Research, 10(46), Pp. 1944-1951

Teplitski, M., Warriner, K., Bartz, J., and
Schneider, K.R. (2011) Untangling metabolic and communication networks: interactions of enterics with phytobacteria and their implications in produce safety. Trends Microbiol 19: 121- 127.

Thaker, H. C., Brahbhatt, N. and Nayak, J. B. (2012) Study on occurrence and antibiogram pattern of Escherichia coli from raw milk samples in Anand, Gujarat, India. Veterinary World 5 556-559

Vendramin, T., Kich, D. M., Molina, R. D., Volken de Souza, C. F. Salvatori, R. U. Pozzobon, A., Bustamante-filho, I. C. (2014) Molecular screening of bovine raw milk for the presence of Shiga toxinproducing Escherichia coli (STEC) on dairy farms. Food Science and Technology 34 (3)

Wang, S., Zang, S., Liu, Z., Liu,P., Shi, Z, Wei, J., Shao, D., Li, B, Ma, Z., (2014) Molecular characterization of Enterohemorrhagic E. coli $\mathrm{O} 157$ isolated from animal fecal and food samples in eastern China. Scientific World Journal2014.

Yagoub, S.O., Awadalla, N.E. and El-Zubeir, I.E.M. (2005). Incidence of some potential pathogens in raw milk in Khartoum North (Sudan) and their susceptibility to antimicrobial agents. Journal Of Animal Veterinary Advance., 4: 341-344.

\section{How to cite this article:}

Okechukwu, E.C., E.U. Amuta, G.M. Gberikon and Njoku, M. 2019. Occurrence and Seasonal Variation of Escherichia coli Isolated from Unpasteurised Raw Milk and its Products Sold in Abuja Metropolis, Nigeria. Int.J.Curr.Microbiol.App.Sci. 8(05): 1979-1988. doi: https://doi.org/10.20546/ijcmas.2019.805.230 